\title{
A Portrait of the Capacity of Public Service Innovation in the Surakarta City Government
}

\author{
R. Slamet Santoso ${ }^{1}$, Hesti Lestari ${ }^{2}$, Dewi Rostyaningsih ${ }^{3}$ \\ \{rssantoso@lecturer.undip.ac.id ${ }^{1}$ \} \\ Universitas Diponegoro, Indonesia ${ }^{1,2,3}$
}

\begin{abstract}
The Surakarta City Government is known as one of the areas that is progressive in its public services, but there are still several problems in its innovation development. The purpose of this research is to get an overview of the capacity of public service innovation in the Surakarta City Government. This research uses descriptive qualitative method. The results show that the Surakarta City Government has bureaucrats or officials who are ready to face change, have good understanding and skills in developing innovation capacity, this is evidenced by sufficient experience in the process of developing the sustainability of public service innovation. The conclusion of this research confirms that the development of innovation capacity is a determinant in improving public services, innovation capacity requires understanding, experience, skills, and diversity, all of which are well managed. The most important recommendation of this research is related to the development of institutional forms of public service innovation in each work unit, to be used as a medium for transmitting the value of change so that they are accustomed to generating innovative ideas and realizing them in various forms of innovation in improving public services in a sustainable manner.
\end{abstract}

Keywords: Innovation Capacity, Public Service, Regulation, Policy, Institution, Value

\section{Introduction}

Decentralization has made local governments have broad authority in managing public services according to public aspirations. Public services are a priority in every public sector organization, supported by various policy mandates from the level of laws to regulations at the technical level (at the Ministry/Institution and Local Government levels). The role of government will greatly determine the quality of policies, therefore local governments must be able to find effective strategies through innovative policies and programs.

In line with the development of information and communication technology, public services are required to be better based on service standards. Nevertheless, efforts are still made to improve conventional services, for example, those related to guidance and empowerment. In order to respond to the various demands for service quality improvement, public service innovation is an obligation. Since 2014, public service innovation has been improved, as evidenced by various public service innovation competitions until now. Now innovation is in an era of disruption and VUCA (volatility, uncertainty, complexity, and ambiguity), which means that innovation has become the key to winning the competition at all levels and sectors. In an effort to respond to these changes, many government units in Indonesia have been consciously moved in the last five years. 
In the midst of the tumultuous industrial revolution 4.0 and the development of the digital industry globally, Indonesia is currently still far behind in terms of innovation, with only being ranked 85th out of 129 countries. The level of innovation activity is obtained from the Global Innovation Index (GII), launched in 2007 by Cornell University and built to foster national innovation strategies, the international debate on innovation and to formulate policies, which aims to compare the relative performance of innovation systems between countries by analyzing strengths and weaknesses - as well as to stimulate the absorption of innovation indicators in surveyed countries [1].

Table 1. Innovation Index of ASEAN Countries 2018-2019

\begin{tabular}{|c|c|c|c|}
\hline Ranking 2019 & Country & Ranking 2018 & Change \\
\hline 8 & Singapore & 5 & -3 \\
\hline 35 & Malaysia & 35 & 0 \\
\hline 42 & Vietnam & 45 & 3 \\
\hline 43 & Thailand & 44 & 1 \\
\hline 54 & Philippines & 73 & 19 \\
\hline 71 & Brunei & 67 & -4 \\
\hline $\mathbf{8 5}$ & Indonesia & $\mathbf{8 5}$ & $\mathbf{0}$ \\
\hline 98 & Cambodia & 98 & 0 \\
\hline \multicolumn{4}{|c|}{ Source: Global Innovation Index. } \\
\hline
\end{tabular}

The performance of local government units is still low in the development of innovation (and replication) of public services. In the 2019 Public Service Innovation Competition (KIPP), there were 3,156 proposals to enter the Public Service Innovation Information System (Sinovik), this number increased from the 2018 Public Service Innovation Competition (KIPP)which reached 2,824 proposals. Proposals that passed administration at the 2019 Public Service Innovation Competition (KIPP)were 1,329 proposals. The thousands of innovations consist of 21 ministries, 13 institutions, 28 provinces, 206 districts, and 62 cities.

At first glance, these many innovations are actually not enough, when compared to the number of work units within the government (ministries/agencies/regions) which almost reaches 100 thousand work units. Another thing that needs to be considered in the development and growth of innovation in the regional government which is still dominated by the regional government of western Indonesia, especially the island of Java.

Surakarta is one of the areas that are progressive and innovative in public services, as evidenced by the many appreciations that have been received from various public service innovation competitions. The development of the city of Surakarta cannot be separated from the long history of Surakarta. The city of Surakarta has had innovative Organizational Culture as well as its identity as a City of Culture since the days of the kingdom, seen from the progress of building architecture and various cultural innovations to the emergence of the PERS Monument, PON Monument, Lokananta, and so on.

Local governments must continue to build capacity to respond to dynamics and public demands. Capacity is related to three dimensions, namely (1) the dimension of human resources (human resources); (2) organizational dimension (organizational strengthening); and (3) the dimension of institutional reform. Each dimension of capacity has a specific focus and types of efforts that must be made to develop each focus on each dimension of capacity [2].

The development of public service innovation in Surakarta City is still not optimal in terms of human resources. Many of the regional apparatus still lack understanding of innovation. Not many regional officials have experience and practice in developing public innovation. This is 
because the resource training program in the Surakarta City Government has not been optimal, so the results of the leadership education and training (DIKLATPIM) have not been optimal to encourage participation in the national innovation competition.

In terms of regulatory or policy support, the current development of public service innovations is still not optimal. Not many government agencies have established policies or regulations that require all technical units under them to make continuous innovations. The development of innovation in government circles is also constrained by the unclear management of administrative authority, which has an impact on the weak priority of institutional development steps and supporting resources. In principle, the innovation authority must have a special institution that handles, both at the central and regional levels, so that all policy steps can be carried out more optimally.

\section{Method}

\subsection{Theory}

Public Service Innovations. Public service and innovation are a necessity, all public sector entities strive to improve their performance, and this can be obtained if innovative thoughts and practices develop in the bureaucracy. As the opinion of Osborne [3], in the article Sustainable Public Service Organization: A Public Service-Dominant Approach, states that there are seven proposals for sustainable public service practices. This proposition has been summarized in the following figure, which shows seven (7) elements for developing a sustainable service organization: SERVICE (System, Engagement, Relationship, Value, Innovation, CoProduction, Experience). The fifth proposition places the importance of innovation for public sector organizations explicitly. Business growth for public sector organizations is based on innovation - not as a means of achieving competitive advantage but rather as a means of achieving service efficiency and effectiveness [4].

Innovation Capacity. The capacity to innovate is one of the critical differentiating factors among public organizations. Innovation capacity is the ability of an organization to develop comprehensive, systemic, and holistic innovations, and involve broader and higher quality participation. An organization with a strong capacity to innovate shows continuous innovation, produces superior results, and encourages social change towards improving life as a whole.

The capacity to innovate can be seen through the organization's condition with the innovative organization's characteristics. The nuances of the capacity to innovate can be inferred from the characteristics of an innovative organization. There are three things related to organizational innovation capacity [5]: 1) The characteristics of an innovative organization, 2) Factors that influence innovation capacity, and 3) Innovation patterns as a reflection of the capacity to innovate [6].

\subsection{Earlier Research}

Muhammad's [7] research results through qualitative and quantitative research methods, applying the concepts of New Public Management, Reinventing Government, and Entrepreneurship Government reveals that local government innovation must be based on strengthening local management capacity governments. They are strengthening management capacity through financial governance reforms, developing matrix organizations, implementing mobile Government, regional performance allowance policies, and individual performance 
appraisals [8]. Graham Orange et al. [8] conducted a study on local government innovation with the development of public values. This study develops a model of the value of local government innovation based on three correlated dimensions. The three dimensions of innovation value include the people dimension, the process dimension, and the technology dimension. So that in measuring the public value of local government innovation, it must be based on the three dimensions in an integrated and holistic manner [2].

In his research, Kim [9] revealed that managerial quality is the main element of innovation, so it cannot be ignored even though it fluctuates. Japanese and American practices influence the quality of management (innovation) in Korea, and the influence of European management is not so visible in practice [10]. Palm and Algehed [11] in the article Exploring Enablers of Innovative Quality Development in Public Administration. Therefore, this study aims to determine empirically which - of the various enabling factors for innovation - may be most important for a specific process step for moving from idea to innovation implementation in the context of public administration and for identifying additional enablers for innovation quality development [7].

Capuno [4] examines the importance of regional leaders' position as the primary driver of government innovation in their respective regions. Then Hennala et al. [12] examined the process of public service innovation involving multi-actors. As a result, this open innovation model recognizes primarily the entry of outside information and knowledge from service users that can generate new and value-added insights into the innovation development process.

Pekkarinen et al. [10] conducted a study entitled Clashes as Potential for Innovation in Public Service Sector Reform. His research results are to reveal the various pressures that influence the level of innovation and manifest as clashes and become controversies between the old way of thinking and the new way. But they can provide a solid foundation (platform) for innovation to be openly analyzed and facilitated [10].

Yohanitas [13] with a research entitled Creating Good Governance through Public Service Innovation in Surakarta. The result of his research is the City of Surakarta's success in developing innovation into an attraction, even though it has changed leadership. Innovative programs keep on rolling, such as public health maintenance, Child Incentive Cards, Digital Population Archives, 1 hour ID card services, and so on. Besides, it is also cooperation between stakeholders and the community to make the innovative program the flagship and pride of the Government of Surakarta [14].

Putri and Pambudi [15], with the results of research showing that innovation in birth certificate services through e-Government in the Department of Population and Civil Registration of Yogyakarta City is not optimal [11].

There are many perspectives on innovation studies in the bureaucracy or the public sector. However, they have not been thoroughly reviewed related to the comprehensive innovation development process that converges on the model of developing public service innovation capacity in local Government. As a new thing that will be examined as a development of the results of previous research in this field, this research will be emphasized on the issue of the innovation capacity of public service units, which will then be developed into a model proposal for developing the capacity of public service innovation in the bureaucracy, especially local governments. 


\section{Result and Discussion}

This section will present policy analysis stages, including problem formulation, purpose formulation, and discussion.

\subsection{Problems}

1) Weak understanding of what public service innovation is;

2) Limited experience and practice of developing public service innovations;

3) Variety of handling models among various government work units;

4) The problem of quantity and quality of bureaucratic resources in developing public service innovations.

\subsection{Purpose}

Based on the main problems found in the development of public service innovation in Local Government, the following research objectives are formulated, namely to describe the capacity of public service innovation in the Surakarta City Government.

\subsection{Discussion}

\subsubsection{Authority Innovation Capacity}

The authority in carrying out the effectiveness of innovation development in Surakarta is not optimal. Regarding the differentiation and decentralization of innovation development in the City of Surakarta, there are currently still tug-of-war and throwing between government departments regarding coordination. Based on the results of an interview with Budi Winarno, until now regional body for planning and development (Bappeda) is the cornerstone of innovation development. However, the problem is that Bappeda does not yet have researchers, but with the task of developing innovation, Bappeda is overwhelmed. Until now, in developing innovation, Bappeda has always collaborated with Universities in the city of Surakarta.

\subsubsection{Regulatory and Policy Innovation Capacity}

Based on the analysis results in the policy aspect, Surakarta City does not yet have regulations regarding regional innovation at all levels. This was evidenced by the exposure of all resource persons at each interview session. The city of Surakarta only provides a legal umbrella for selected innovations. Therefore, not all innovations in Surakarta have a legal umbrella. Based on the results of the interview with the Assistant Regional Secretary, Rakhmat Sutomo, it was explained that this was possible because the basic Mayor is a field person, so regulations are often overlooked, the important thing is to go forward and take concrete action according to the needs of the community. He explained that the principle of the Mayor is budget will be returned for the welfare of the people.

\subsubsection{Capacity for Innovation Commitment and Leadership}

There is one critical success factor behind the massive emergence of innovation in Surakarta, namely the commitment and strong leadership emitted by Surakarta leaders. 
Innovation should indeed be contained in an organization's values and can encourage people to come up with various new ideas [5][6].

The Mayor of Surakarta has a very high commitment to innovation in the city of Surakarta. Based on an interview with the Assistant Regional Secretary, Rakhmat Sutomo, the Mayor has a strong commitment to innovation. The Mayor has the advantage of providing ideas for the name of the innovation made by the Regional Apparatus Organization (OPD). In the four interview sessions, each session stated that the Mayor's commitment to innovation was very high. The Mayor is also very receptive to input and criticism from various parties because this is a momentum to improve. Regarding the urgency of innovation for the regions, it turns out that not all elements support this. Based on an interview with Zainal Arifin, it was explained that Solo's innovation competitions had not been considered necessary by the Solo City Regional Representative Council (DPRD) and the Regional Government Budget Team (TAPD).

\subsubsection{Value and Cultural Innovation Capacity}

Regarding the institutionalization of values and a culture of innovation, based on the results of interviews, it was found that State Civil Apparatus (ASN) Surakarta City already has the spirit or spirit to innovate. This was done starting from how to solve the problems that existed in each Regional Apparatus Organization (OPD). By solving these existing problems, Regional Apparatus Organization (OPD) will issue innovations so that the problem is resolved. Innovations in Solo come from almost all elements, from top managers to bottom managers. Based on an interview with Arthaty, the Health Office, it was explained that the innovations in Solo City at the Health Office came from the forefront. However, after the Education and Training Center, middle managers also made innovations. Arthaty stated that the encouragement of innovation in the Education and Training Center became something that was forced. In fact, according to him, innovation must start with creative ideas. Besides, innovation also often has to be linked to technology, because if the innovation does not use technology, innovation is considered flawed.

\subsubsection{Institutional Innovation Capacity}

Regarding the escort of innovation in the institutional sector, based on the interview results, there was no finding of an ad hoc / task force team specifically for innovation development in Surakarta. However, Bappeda has four teams that can oversee innovation, namely the regional innovation system team work (SIDA Pokja), MICE team work, egovernment team work, Thematic Village Development Working Groups, and the Regional Research Council. Based on the interview results, institutionally, there are no specific institutional characteristics capable of innovating. Almost all Regional Apparatus Organization (OPD)have high initiatives related to innovation. This cannot be separated from the Organizational Culture of Innovation in most civil society organizations and the people of Surakarta. In conducting innovation, Surakarta City has been reactive until now, which means there are problems; there are solutions, namely innovation. This was obtained based on the results of interviews with Zainal Arifin, Arthaty, and Rony.

\subsubsection{Resource Innovation Capacity}

Human resources are the key to all development planning and program implementation in organizations [14]. According to Moh. Zainal Arifin, the regional innovation expected by the Mayor, is innovation in sustainable digitalization. It can have a positive impact on the efficiency 
and effectiveness of public services (public). However, most Regional Apparatus Organization (OPD still have the perspective that good innovation is only technology-based innovation, even though innovation itself has a variety type. According to Budi Winarno, head of research and development sub-sector (Head of Research and Development Sub-sector), Regional Apparatus Organization (OPD) human resources in Surakarta are very enthusiastic to see the opportunity for innovation that starts from the results of a joint discussion discussing a problem. Arthathy (Head of the Information Systems Section of the City Health Department/DKK) added that Regional Apparatus Organization (OPD) in Surakarta had high creativity and initiative to solve problems through innovation a long time ago. The nature of the initiative of the Regional Apparatus Organization (OPD in Surakarta City is also supported by the existence of Leadership Education and Training (Diklatpim) to optimize creativity for the emergence of various innovations to support the public services of Surakarta City.

Based on the interview results, the existence of the Education and Training Team was not optimal. This is because the innovative work produced by the Education and Training Team is not encouraged to participate in innovation competitions. However, on the other hand, the existence of Leadership Education and Training (Diklatpim) also produces useful innovations for the community, one of which is the Population and Civil Registration Agency (Disdukcapil) in your hands. An innovation originating from the Education and Training Center, until now, this innovation is still being used, even the innovators directly socialize and introduce the innovation. Regarding the results of the proper repairs, it must be seen from how the proper is made. If the Regional Apparatus Organization (OPD does not make the Program of Change (PROPER) seriously, then the journey will not be sustainable and end up in the closet and not seen. Judging from one year after graduation, the number of which are significant and still in operation is less than $50 \%$. According to Amelia, One-Stop Integrated Services and Investment Service's (DPMPTSP's) Information Section, PROPER's existence, which is always new every year, makes the PROPER unsustainable because it is always improving every year.

\section{Conclusion and Recommendation}

The development of innovation capacity is a determinant in improving public services. The capacity for innovation certainly requires understanding, experience, skills, and diversity, all of which are well managed. As for the recommendations for developing institutional forms of public service innovation in each work unit, it should be used as a medium for transmitting the value of change so that they are accustomed to generating innovative ideas and realizing them in various forms of innovation in sustainably improving public services.

\section{References}

[1] M. K. Kawabata and A. S. Camargo Junior, "Innovation and institutions' quality: a comparative study between countries," Int. J. Innov. Sci., 2020.

[2] M. S. Grindle, Getting Good Government: Capacity Building in the Public Sector of Developing Countries. Boston: Harvard Institute for International Development, 1997.

[3] S. P. Osborne, Z. Radnor, T. Kinder, and I. Vidal, "Sustainable Public Service Organisations: A Public Service-Dominant approach,” Soc. Econ., vol. 36, no. 3, pp. 313-338, 2014.

[4] J. J. Capuno, "Leadership and Innovation Under Decentralization: A Case Study of Selected Local Governments in the Philippines," 2010-10, 2010.

[5] B. E. Wilfridus and A. J. Purwanto, Materi Pokok Inovasi dan Perubahan Organisasi, 2nd ed. 
Jakarta: Universitas Terbuka, 2016.

[6] R. Jain, “Innovation Management: Conceptualization for Practice,” Indian J. Ind. Relat., vol. 52, no. $2,2016$.

[7] F. Muhammad, Reinventing Local Government: Pengalaman dari Daerah. Jakarta: Gramedia, 2009.

[8] O. Graham, T. Elliman, A. L. Kor, and R. Tassabehji, "Local Government and Social or Innovation Values,” Transform. Gov. People, Process Policy, vol. 1, no. 3, pp. 242-254, 2007.

[9] K. P. Suk, "Quality as a Reflection of Innovation? Quality Management in the Korean Government," Int. Rev. Adm. Sci., vol. 75, no. 419, pp. 421-435, 2009.

[10] S. Pekkarinen, L. Hennala, V. Harmaakorpi, and T. Tura, "Clashes as potential for innovation in public service sector reform,” Int. J. Public Sect. Manag., vol. 24, no. 6, pp. 507-532, 2011.

[11] P. Klas and J. Algehed, "Exploring Enablers of Innovative Quality Development in Public Administration," Int. J. Qual. Serv. Sci., vol. 9, no. 2, pp. 203-217, 2016.

[12] L. Hennala, P. Satu, and U. Tuomo, "Challenges of multi-actor involvement in the public sector front-end innovation processes Constructing an open innovation model for developing well-being services," Eur. J. Innov. Manag., vol. 14, no. 3, pp. 364-387, 2011.

[13] W. A. Yohanitas, "Menciptakan Good Governance Melalui Inovasi Pelayanan Publik di Kota Surakarta," vol. 12, no. 3, pp. 239-258, 2016.

[14] I. N. Wamar, J. Dewayani, and A. T. Ferdinand, "Strategic Human Resources and Knowledge Sharing: How do Enhancing Organizational Innovation?," Qual. J., vol. 20, no. 168, 2019.

[15] E. K. Putri and A. Pambudi, "Inovasi Pelayanan Akta Kelahiran Melalui EGovernment di Dinas Kependudukan dan Pencatatan Sipil Kota Yogyakarta," vol. 6, no. 1, pp. 69-84, 2018. 